\title{
Architecture of Stalingrad: the image of the hero city by the language of "Stalinist Empire style"
}

\author{
Galina Ptichnikova ${ }^{1,2 *}$, Alexey Antyufeev ${ }^{2}$ \\ ${ }^{1}$ The Scientific Research Institute of the Theory and History of Architecture \& City Planning, \\ Moscow, 111024, Russia \\ ${ }^{2}$ Volgograd State Technical University, Volgograd, 400005 Russia
}

\begin{abstract}
The article is dedicated to the peculiarities of the architecture of "Stalinist Empire style" by the example of Stalingrad architecture. This city was restored again after Stalingrad battle which took place in the period of 1942-1943, in accordance with the principals of socialist urban construction. Reconstruction of Stalingrad is considered by the authors of the article as the creation of a new type of a Soviet city - a Hero City. The authors reveal the artistic features of architectural ensembles and buildings designed according to the principles of "Stalinist Empire style".
\end{abstract}

\section{Introduction}

Post-war reconstruction of Stalingrad became an important stage in the architectural life, not only for the city, but for the whole country - URSS - as well. The architects were supposed to show the contours of a happy future life appearing through a harsh daily routine. Creation of visual artistic images of the city was decided by means of Soviet neoclassics, which in the post-war period obtained peculiar characteristics which allowed them to be distinguished in a style that is now referred to as "Stalinist Empire Style". The present article is dedicated to the peculiarities of form making of architecture of Stalingrad during the second half of the $1940 \mathrm{~s}-1950 \mathrm{~s}$.

\section{Search for a new style}

Starting from the year of 1943, immediately after the battle of Stalingrad and liberation of the city by the Soviet forces, the Soviet Academy of architecture, the Institute of Urban development and Architectural planning of Russian Soviet Federative Socialist Republic (RSFSR) embarked on development projects of Stalingrad reconstruction.

The important ideological requirement for the establishment of an appropriate architectural and artistic image of the reborn Stalingrad was the high value of the city in the "table of ranks" in the hierarchy of Soviet cities of that time (In accordance with the Decree of the Presidium of Armed forces of the RSFSR, September 4, 1945 the city of Stalingrad was singled out into independent administrative and economic center with its own budget and is classified as a city of republican subordination ("Vedomosti" of the USSR, 1945, 30

*Corresponding author: ptichnikova_g@mail.ru 
November, no. 79 ( 406). p. 2). Artistic image of post war mentality contributed to the idea of Stalingrad reconstruction as the creation of a new type of the city - a "Hero-City". Two main themes, influencing the search of the architectural image of a "Hero-City" were the theme of the triumph of victory in the great patriotic war and the theme of creating objects, monuments of Soviet history events. The feeling of absolute exclusiveness and importance of its universal values explains the desire of architects to capture these values in the ensembles of the city-monument and extrapolate them into the future.

Another important factor that influenced the creation of a new architectural look of the city, was that Stalingrad had been, in fact, the City - Symbol, the city of the leader, the city of the head of the State, named after him, the city with history, connected with destiny and related victories of its leader. The Chief Architect of Stalingrad P.I. Buchnev, describing the General city planning scheme of 1943, stressed the role of architecture, meant to be compatible with the name of the great Leader: "The envisaged reconstructive activities, updated residential and public development, a number of new architectural ensembles will turn Stalingrad into an exemplary well-arranged, genuinely socialist city, worthy of the great Stalin" [1]. It is worth mentioning that toponymy of Stalingrad was based on the name of the leader of the Soviet State. The main street of the city was named after I.V. Stalin, also there were Stalin Embankment and Stalin District. Among the proposals on the creation of the city center the possibility of the construction of the Palace of Stalin had been considered [2, p.41]. Many monuments to the leader were built in the city including the world's highest bronze sculpture of Stalin which was constructed in 1952 (Fig.1). Thus, the search for architectural solutions in restoration and reconstruction was made to be aimed at identifying the special status of the city.

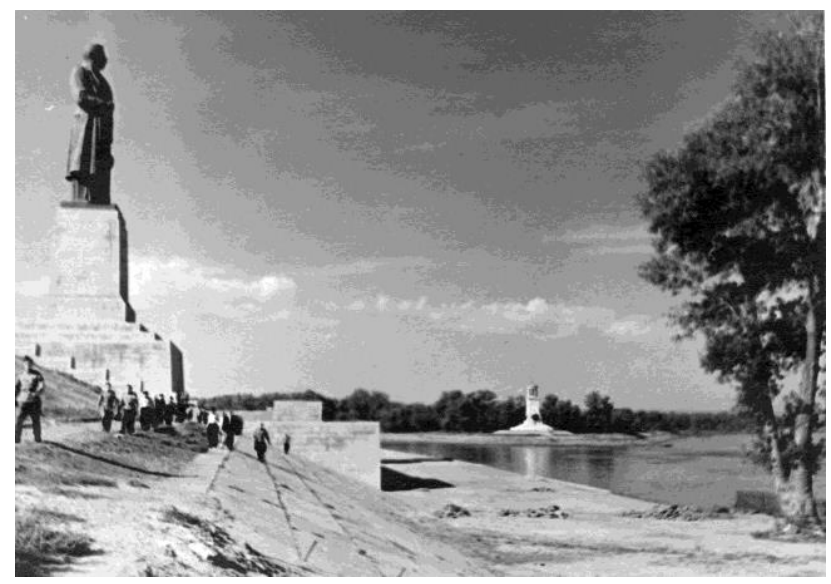

Fig.1. Stalin's Monument at the entrance to the Volga-Don channel (dismantled). Sculptor E. Vuchetich. Photo by L. Nyman. 1950s.

The style, most in response to the decision of such kind of ideological tasks, was the style common in Soviet post-war architecture based on classical heritage which was called "Stalinist Empire style". Architecture was perceived as a mean to approval of morality, heroism, citizenship. The mission of propaganda of the deed was no less important than the various technical tasks of restoring of environmental assets. "Architecture of Stalingrad must be of high quality, the heroic spirit of the city, achievements and victories of the Soviet people under the leadership of the Lenin-Stalin party should be reflected in public buildings by means of the plastic arts", - this is the way the main artistic challenge for master plan designers was described by V.N. Simbircev, appointed the Chief Architect of Stalingrad in 1944 [3]. 


\section{Ensembles of the center of Stalingrad}

Ensemble style, monumentality and artistic integrity of buildings have become the distinguishing features of not only the center but also of other areas of Stalingrad, built in the style of post-war architecture. The idea of the architectural ensemble in those years perceived as the main in Soviet architecture. The city as an object of an artwork was built through a system of ensembles, consecutively located one after another and strung on axle of the main city arterial road - Stalin Avenue (Lenin Avenue at present). This clear system had become the foundation, which helped to bring the city arrangement together.

However, the implementation of the principle of ensemble in practice caused some difficulties. Natural development of actively recovering city did not fit into the principles of perfect ensembles statics. Therefore, no wonder that while working on the master plan of Stalingrad in 1948-1954, proposals for changing the boundaries of the city by means of its reduction had been considered [3; 4]. Due to the apparent impossibility of creating of a unified ensemble of the city which stretched almost $70 \mathrm{~km}$ along the Volga River by that time, the question of the reduction of the city territory and removal of the southern areas of Stalingrad from a planning "carcass" so as to form a separate city of Krasnoarmeysk was raised. Thus, the desire to create a city as a single compositional system resulted in the search for the architecture and town planning decisions concentrated on relatively small territory in comparison with the total area of the urban organism. By 1946 a drafted detailed design of the center planning of Stalingrad was developed (K.S. Aalabyan, N.H. Polyakov, D.M. Sobolev, A.E. Pozharsky, Butyagin V.A., etc) (Fig.2).

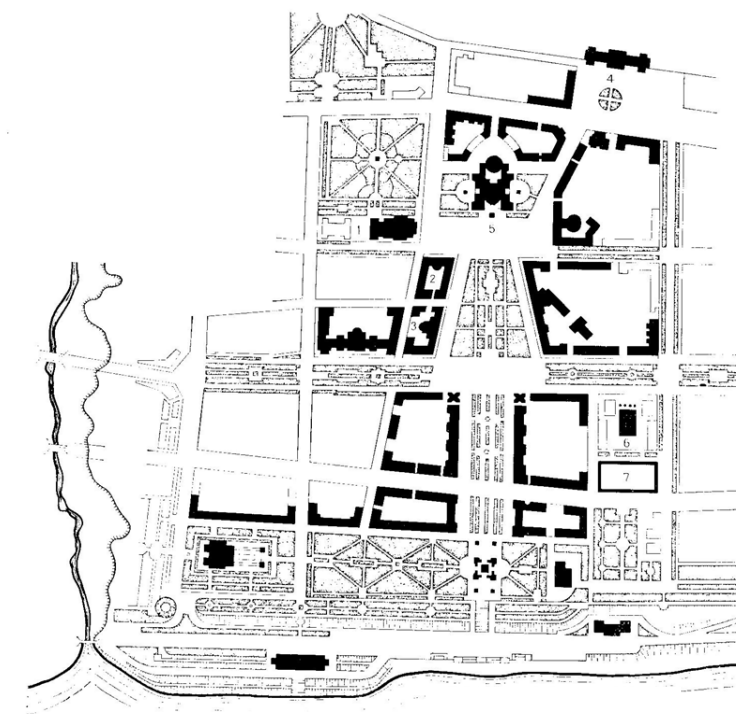

Fig.2. The project of the central part of Stalingrad.

Draft design of the central part of Stalingrad, executed under the direction of K.S. Alabyan, consisted of all the principal statements subsequently developed and fixed in the master plan of the city [5]. The central part of Stalingrad was built as a system of squares and avenues running perpendicular to the main arteries of the city. The area of the square of Fallen Fighters which was visually connected with the square of Demonstrations in front of the planned House of Councils acquired the dominant value. Through a wide Alley of Heroes, this area was connected with a new square of Victory at the Volga River Embankment. Descent to the river ended with a monumental staircase. In accordance with the principles of the ensemble in a socialist city there should necessarily be such elements 
as "gates to the city". The propylaea became the river gates to Stalingrad from the Volga side (architects: V.N. Simbircev, I.E. Fialko, V.S. Makarenko) (Fig.3). The image of the propylaea is similar to ancient designs. The propylaea, built in 1952, was established by two Doric porticos consisted of eight columns and arranged symmetrically along the axis of the direction of the stairs going down to the lower level of the embankment and the river. The propylaea pass through the main compositional axis perpendicular the Volga, pointing to the infinity of Volga horizon.

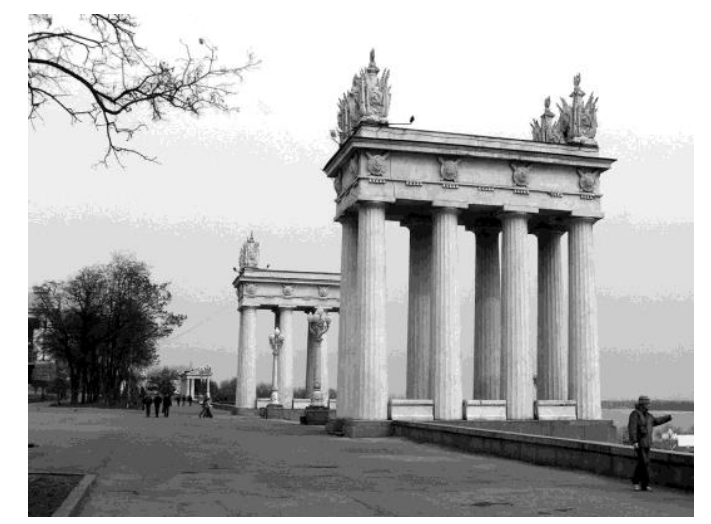

Fig.3. Propylaea stairs on the embankment of Volgograd. Arch. V. Simbirtsev. I. Fialko, V. Makarenko. Photo by G. Ptichnikova.

The central part of Stalingrad almost fully met strict theory of Soviet urban planning of the post-war period, which led to the conceptualization on how to build the city. For example, "seven conditions for the establishment of the city", which were listed by A.G. Mordvinov in 1945 at all-Russian conference of chief architects. [6, p.33].

The first condition is the link of the city with natural environment, revealing its beauty. In accordance with the new general plan the main artistic and logical focus of the center of ensemble was transferred to the shore of the Volga River, where the new town's main square was meant to link the city with the river [7]. River views are rhythmically opened through the transversal deep perspective. Compositionally built green embankment gave the opportunity to observe Stalingrad in all its artistic integrity from far points of the river.

The second condition was the establishment of a clear compositional center. It was executed by the main street — Stalin Ave, which through the Alley of Heroes was connected with central squares - Fallen Fighters square, newly designed "Square of Victory" and Railway Station forecourt (Fig.4, 5).

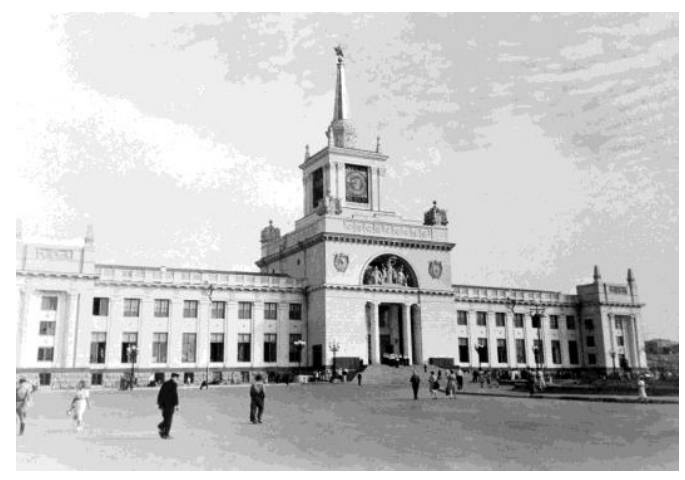

Fig.4. Railway Station forecourt. Arch. A. Kurovsky, S. Briskin. Photo by L. Nyman, 1954. 


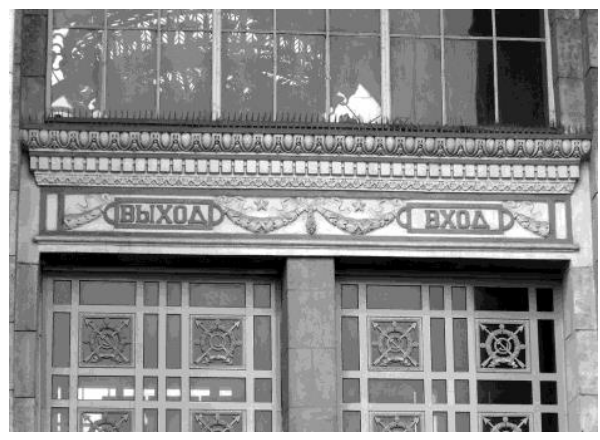

Fig. 5. Detail of the entrance of the railway station. Photo by G. Ptichnikova.

Principles of ensemble, light coloring of buildings and some other characteristics correspond to seven conditions. Unfulfilled was the only condition - establishment of the largest public building with high-rise urban composition in the main architectural node the House of Council. After numerous competitions in 1952 L.V. Rudnev and V.O. Munz developed a project in accordance with which the House of Council was located exactly on the axis of the esplanade leading from of the Volga. The draft project was similar to the composition of Moscow high-rises and was practically "twin brother" of the House of Science and Art in Warsaw. However, due to a number of reasons the construction of the House of Council, in accordance with this project had not been initiated. Difficult searches for compositionally shaped characteristics of the main ensemble in Stalingrad were interrupted and were not completed. The symbol building, which ought to reflect the Stalin epoch, remained a monument of "paper architecture". Searches continued until the late 1980s and stopped in connection with the decision of the authorities to restore the Cathedral of Alexander Nevsky, which had been destroyed in 1932.

Stalin Avenue, stretching nearly twenty kilometers, acquired special significance as the main compositional axis, linking the city center with its suburbs. According to the development pattern the avenue was divided into several parts. The facades of the houses along the Avenue of Stalin, built in the early 1950's, served as a kind of theatrical scenery and background settings for demonstrations and festivals. The avenue development was carried out in accordance with the design of Stalingrad architects, among which one should mention A.V. Kurovskiy, M.F. Hohriakova, Z.D. Gorbushin, F.M. Lysova, D.V. Ershov, V.P. Statun, G.F. Borysenko. [7; 8].

\section{4 "Empire" working areas}

In the "Stalinist Empire style" in order to create an atmosphere of pageantry and splendor, the architecture of the Metal City (as northern areas of Stalingrad were called) had been solved. Development of streets and avenues of the working districts near "Stalingrad Tractor" plant, "Red October" plant and "Barricades" plant is characterized by the tower type, balustrades, bas-reliefs and order system. Great attention was paid to plastic art, giving the southern coloring to the developed territory by using bay windows, stanzas, verandas and balconies.

Especially highlighted are lateral streets leading from the depths of the settlementsworking class areas to the main parade city road - Dzerzhinskiy St. , Shtemenko St., Metallurgists Ave, etc. (Fig.6). The houses, overlooking the crossroads, are crowned with towers, "crowns", sculptural stucco. Especially noticeable for its completed image, characterized by art deco, is a nine-storied building (93 Lenin Ave.), located at the intersection of two avenues - Stalin (Lenin) Ave. and Metallurgists Ave. 


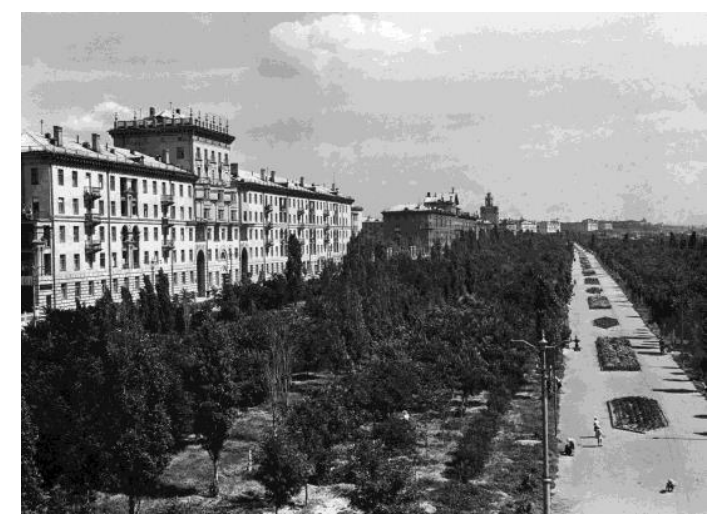

Fig.6. Prospect Metallurgists. Photo by L. Naiman.1950s.

Spatial axis of the main avenue is rhythmically counted by squares, emerging at the intersections with lateral streets, as well as squares close to plants. Dzerzhinsky square, spreading in front of the entrance of "Stalingrad Tractor" plant, is considered to be the end of the Avenue. The eastern side of the square is formed by entrance posts of tractor plant, completed in 1954 by Igor Nikolaev project and the building of plant management.

\section{Sources of inspiration}

The language of the archetypes was the basis of the architectural and artistic manner in post-war Soviet architecture. The search for new techniques of form making were very difficult, because external manifestation of form had to be recognizable, capable to generate historical associations already familiar to the audience, while ideologically finally oriented.

Several sources can be distinguished in the space of the archetypes of architectural forms of Stalingrad. It is, first of all, Russian classicism, which was supposed to reflect the presence of Russian national traditions in the Soviet town. There are many public buildings of that kind in the central part of the city. Among buildings, with the stylistic features of Russian classicism, an object of industrial architecture, known as the administrative building of city water supply ("urban pumping station"), should be mentioned. The building resembles rather a Russian mansion house (architect B.A. Gekker). Rotunda - pavilion with spectacular observation of the Embankment can be considered as one of the images of Russian classics (architect I.R. Arutyunova). Another powerful sources of form making were the examples of Italian Renaissance. The buildings, in which there are transversal, flexibly changing architectural themes of the Italian Renaissance, can be seen in the center of Stalingrad.

Among them - the buildings of the regional Party School, (architects V.N. Simbirzev, E.I. Levitan), the buildings of the hotel "Stalingrad" (architect A.V. Kurovskiy, V. Postoenko) and "Intourist" (architect B.G. Goldman), the administration building of Hydrostroy (architect E.I. Levitan), the building of the State Bank (architect E.I. Obuhov) (Fig.7). 

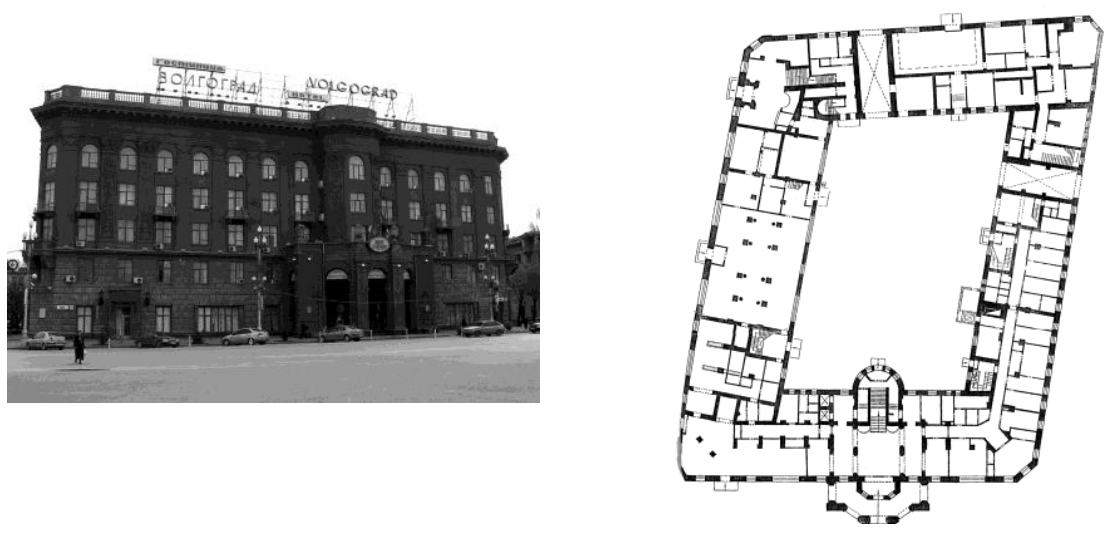

Fig. 7. Hotel "Stalingrad" (at present "Volgograd"). General view, plan., Arch. A. Kurovsky, V. Postoenko. Photo by G. Ptichnikova.

The architecture of the buildings is based on using common techniques of layers on wall façade and deep rustication on the two lower floors. Crowning of the walls in these buildings is decorated with Corinthian pilasters with elements of Soviet symbolism; moved forward cornices, balustrades on top of the buildings, arches, bas-reliefs with vases filled with bouquets of wheat and fruit, decorated components such as garlands of flowers were actively used. The building of the Regional Party School shows clear monumental composition, facades are made of a clear rhythm of pilasters, window openings and entrance stanzas with the contrast of upper smooth and low rusticated floors [9] (Fig.8). As a tribute to the tradition above the main entrance of the Regional Party School, bas-reliefs of classics Communist leaders - Marx, Engels, Lenin and Stalin were installed. The building set the tone of the entire developed area of Fallen Fighters square, defining its scope and nature (Fig.9).

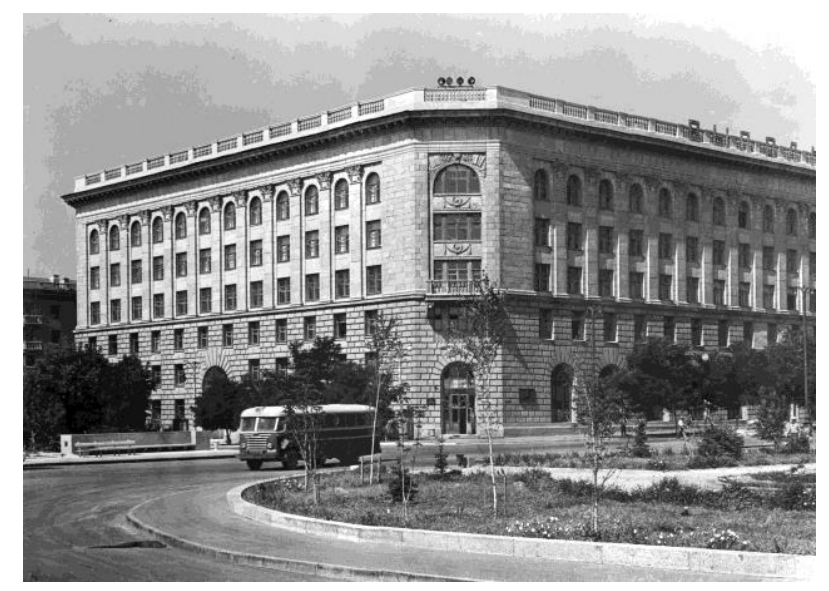

Fig. 8. The building of the Regional Party School. Aarkh. Simbirtsev V.N., Levitan E.I. Photo by L. Nyman.1950-s. 


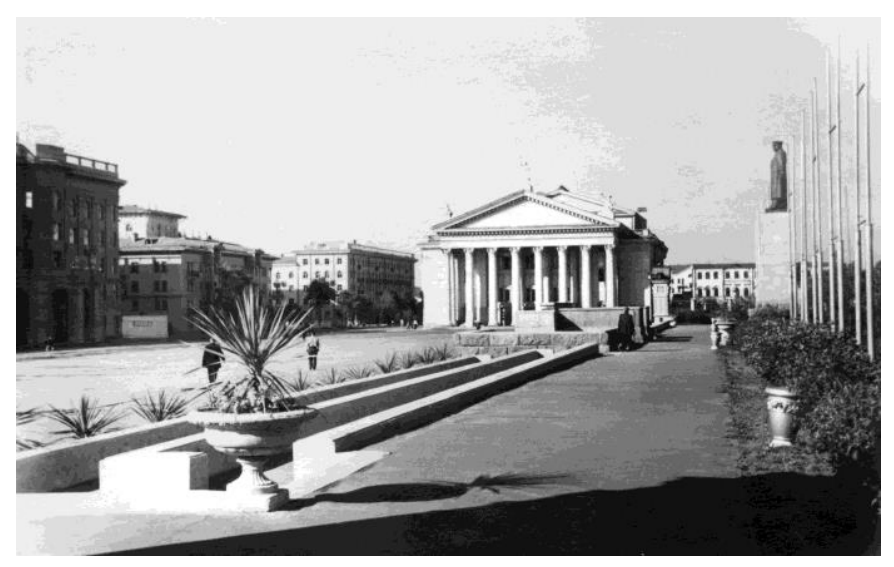

Fig.9. Fallen Fighters square in Stalingrad. Photo by L. Naiman.1954.

"Great" order distinguishes buildings of the Regional Committee of the CPSU (architect E.I. Obuhov, A.S. Kulev) and the Palace of Labour (architect V.E. Maslyaev, F.M. Lysov) (Fig.10).
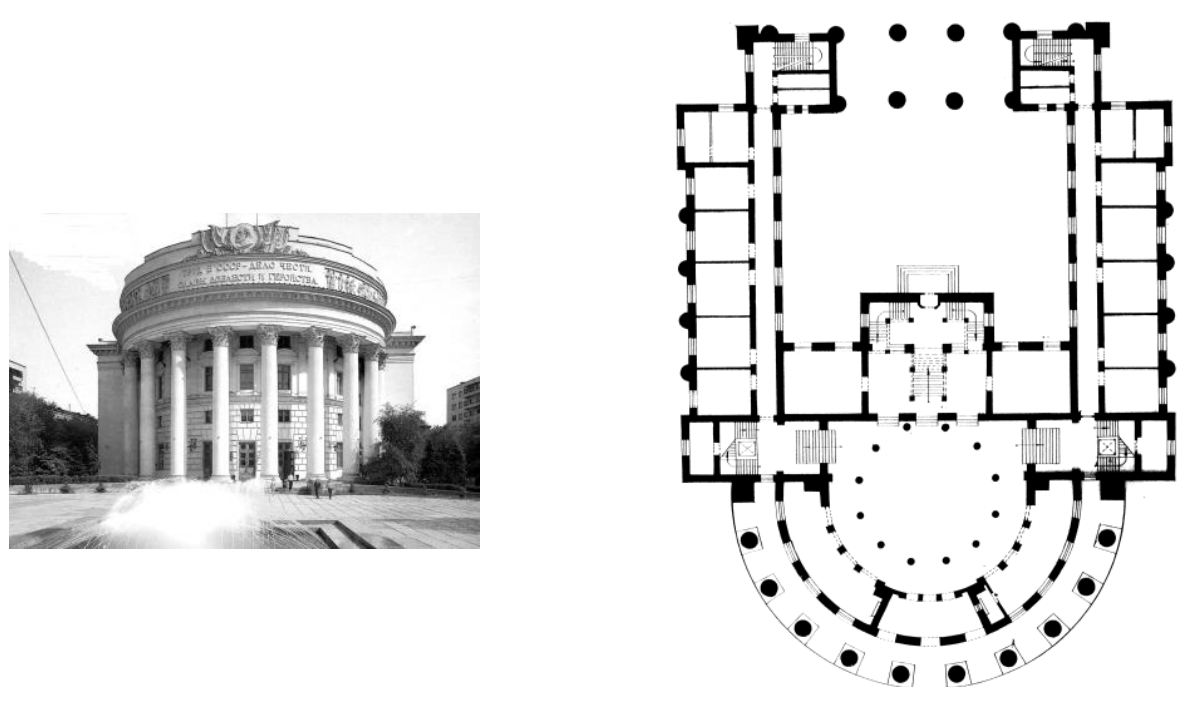

Fig. 10. Palace of Labour. General view, plan of the 1st floor. Arch. V. Maslyaev, F. Lysov Photo by N. Samsonenko, 1989.

The buildings are distinguished by the use of Corinthian order richly decorated with soviet symbols and developed entablature. The Palace of Labour (another name is the House of Trade Unions) had already been completed at the sunset of Stalin era in Stalingrad — in 1957, but on the attic of this building the words Stalin pronounced on the XVI Congress of the AUCP (b) in 1930 are still imprinted: "Labour in the USSR is a matter of honor, glory, valor and heroism“. The entry section of the Palace of Labour is crowned by a sculptural composition with a facial profile of V.I. Lenin and dipped banners. Dripstones, interfloor eaves gutter, columns and pilasters of the Corinthian order are widely used in the architecture of both buildings.

"Empire shine" is visible in many buildings of post-war Stalingrad. One of the most 
striking examples is architecture of residential buildings of Sovetskaya Street (architects S.K. Kobelev, F.M. Lysov, G.A. Rossihin), which was basically completed in 1952-1956. The street is formed by residential buildings, which can be called without much exaggeration - Palazzo House. Large seven-storied buildings are divided into shelves and become various story, thereby simplifying large-scale external look. Facades are filled with sculptures, attics, reliefs in the shape of wheat bundles, large vases and cone firs (Fig.11). Some buildings have large two-storied arch-entrances to courtyards. The pompousness of the facades was projected on interior environment: apartments were complicated by front suites, bay windows.

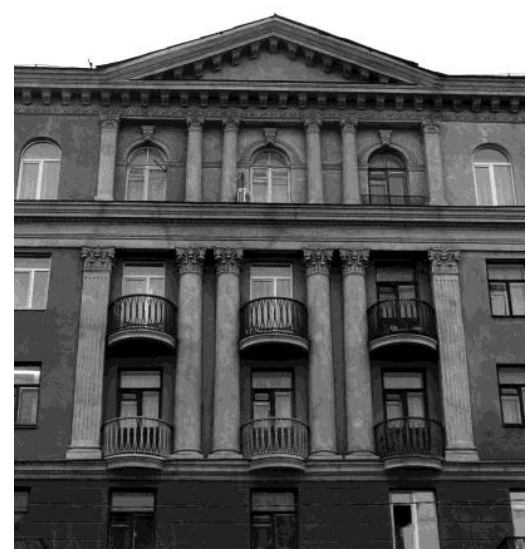

Fig. 11. Sovetskaya Street, house number 28. Arch. S. Kobelev, F. Lysov. Photo by G. Ptichnikova.

A special case of using Italian motifs is a residential building No. 14 in RabocheKrestyanskya street (architect A.V. Kurowsky) which was built in 1949. Venetian elegance and refinement are observed in its architecture. Forms of ways and shells are used in decoration of stanzas (Fig.12). The main façade of the building is decorated with basreliefs, the main motive of which are the symbols of the Volga region - whimsically curved sturgeon bodies.

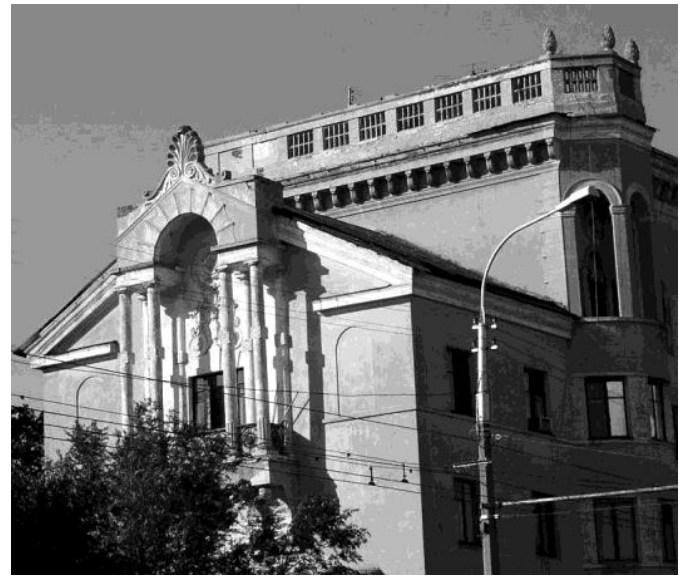

Fig. 12. Residential building № 14, St. Raboche-Krestyanskya. Arch. A. Kurowsky. Fragment of the facade. Photo by G. Ptichnikova. 
Antique designs form the basis of the development architecture of Mira street (architects K.N. Afanasyev, M.I. Sinyavsky, N.A Naumova, E.I. Levitan, A.I. Rubin, Y.N. Telenev ), which became the first street of new Stalingrad, built in the post-war period. Mira Street was created as benchmark ensemble of a residential street with all its components - the beginning, the end of the composition, dominants and spatial pauses. Its length is $550 \mathrm{~m}$, its width is $32,5 \mathrm{~m}$, height of buildings varies from 12 to $18 \mathrm{~m}$. At the end of Mira Street, closing its perspective, in 1954, the Planetarium was built (architect V. N. Simbirtsev, M.A. Homutov) (Fig.13). The beginning of the street was completed much later (in the 1970 's.) by formation of the square near the Palace of Pioneers with picturesque asymmetric composition (architect E.I. Levitan, A.S. Leushkanov).

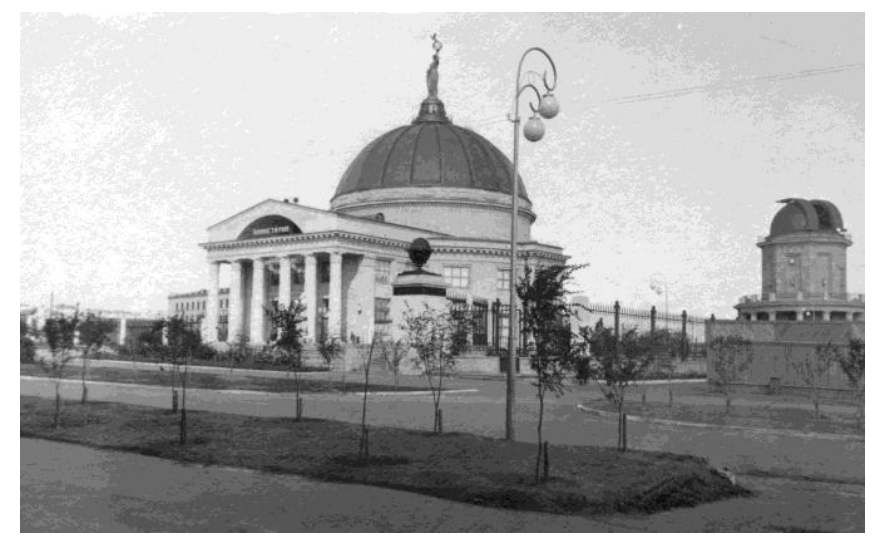

Fig. 13. The Planetarium. Arch. Simbirtsev. Photo by L. Nyman, 1954.

In the central part Mira Street overlooked the Demonstration square where the House of Soviets was supposed to dominate. Therefore, the street space created a ceremonial corridor for festive columns of thousands of demonstrations to approach the tribunes of the foot of the main building of the city. The main part of Mira Street development is represented by the quarters of three-five-storied houses with colonnades, open courtyards, courts of honor and fountains in the depths of the courtyards. Construction parameters, length, and number of stories in the houses; gaps between them were proportionately linked. The facades of residential buildings are formed by stanzas, galleries, sunscreens. The walls are decorated with sunflower rosettes and symbols of opulence: bundles of wheat, garlands and bouquets of flowers. The medallions depict figures of warriors and homefront workers, signs of Soviet symbolism - "hammer and sickle", five-pointed stars, as well as the attributes of military history.

Coloring of buildings has become a kind of town-planning guide in the planning structure of the Centre. Sovetskaya Street is noticeable for dark red ("Pompeian") and darkgray colors. When building Mira Street, by contrast, the Russian classicism colors yellow facades with white details were used. Construction of the city's main square (the Fallen Fighters square) is carried out in monochrome tones using different shades of grey or brown.

\section{Conclusions}

Analysis of features of reconstruction and restoration of Stalingrad for quite a short postwar period, allows following statements to be made.

Architecture in the post-war period was considered to be an effective mean of influence on mass consciousness which was performed by use of images of cultural heritage. 
Experimental search of form making, associated with historic architecture and order system, was focused on the development of architectural language, stylistic means, which could express the emotional-ideological component - the pathos of the Victory of Soviet people in the Great Patriotic War and already foreseeable abundant future of the "Communism tomorrow" (Fig.14). In the post-war architecture of Stalingrad formalaesthetic ideas and examples of Russian classicism, Italian Renaissance and ancient architecture were used as sources of inspiration.

In the post-war architecture due to the perception of the values of that time as universal, inviolable and immutable combination forms of classic past with possible forms of future, occurred.

As a rule ensemble of "Stalinist Empire style" is complete and self-contained. Implementation of one universal classic architectural and urban development model in postwar Stalingrad on a large scale predetermined certain behavior samples and preconceived mode of life of the population. Grand avenues and highways were intended to be used for demonstrations and triumphal processions, squares - for meetings, embankments- for walking. By means of "Stalinist Empire style", the "utopian" model of a Socialist City, was largely idealized and established in Stalingrad. The rigid development hierarchy of postwar neoclassic requires unconditional subordination of new objects to forged order. No wonder how painfully new objects which are introduced into urban space by the life of post-Soviet time are perceived by architectural environment of "Stalinist Empire style" [10].

Thus, the post-war architecture of Stalingrad was the complete embodiment of the ideas made of highly artistic phase of development of the domestic architecture of the 20th century. Its uniqueness lies in the creation of complex ensembles of post-war reconstruction with a unified ideological and stylistic direction as a monument to a great victory. A great advantage of these ensembles is harmonious proportion of space and height of the developed territory, its immensity to the natural landscape, the richness and expressiveness of form making tools, synthesis of architecture and sculpture.

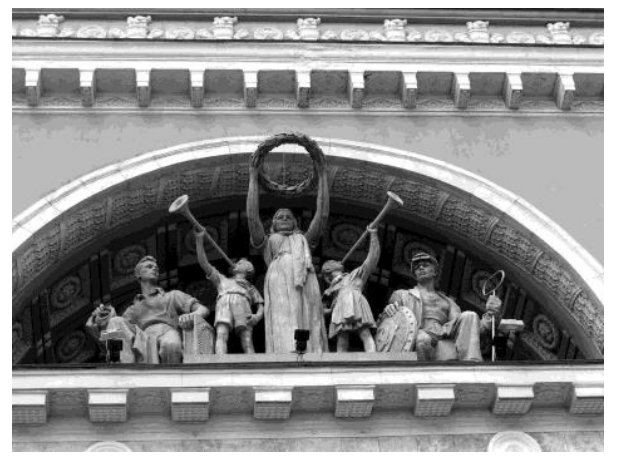

Fig. 14. Detail of the facade of the railway station. Sculptural group "The Apotheosis of Labor". Sculptors M. Pavlovskii, N. Pavlovskaya, V. Bezrukov. Photo by G. Ptichnikova.

\section{References}

1. Characteristics of the chief architect of the mountains. Stalingrad general layout of the city. July 29, 1943. GAVO.F.71.Op.1.D.638. L.99 (in Russian).

2. E.P. Zhorova. Code of historical and architectural heritage of Tsaritsyn-StalingradVolgograd (Volgograd: The Panorama Publ. 2004)

3. V.N. Simbirtsev Conclusion of the chief architect "On the main points of the new 
master plan. Stalingrad". April, 13, 1951 of the city Stalingrad. GAVO.F.71.Op.1.D.1252.L.23 (in Russian).

4. Remarks to the question "The main provisions of the master plan. Stalingrad "April 3, 1954. GAVO.F.71.op.1.D.1459.L.73-77. (in Russian).

5. V.M. Vodolagin, Essays on the history of Volgograd 1589-1967. Moscow: Nauka Publ. (1968) (in Russian).

6. Yu.L. Kosenkova, Soviet city of the 1940s - the first half of the 1950s: from creative exploration to construction practice. Moscow: Editorial URSS Publ. (2000) (in Russian).

7. V.I. Atopov, V.E. Maslyaev, A.F. Lypyavkin, Volgograd. (Moscow: Stroiizdat Publ. 1985)

8. A.M. Vyazmin, P.P. Oleinikov, Architects of Volgograd. (Volgograd: The Publisher Publ, 2003)

9. A.V. Zhuravlev, Yu.L. Kosenkova, Vasily Simbirtsev. (Moscow: Stroiizdat Publ. (1986)

10. G. Ptichnikova, Procedia Engineering (2016), 165, pp.1903-1910. 